\title{
Investment Pattern of Financially Literate Persons in Nepal
}

\author{
Jeetendra Dangol, $P h D^{*}$ and Rohi Shakya**
}

\begin{abstract}
The paper investigates the investment pattern of financially literate persons based on 314 individual investors of Nepal. The mean, ANOVA and logistic regression is used. The results show that investors have higher level of financial literacy level. Among them, male participants, investors of age group 20-30 and income level of Rs 50,001 and above scored higher in financial literacy. The financial literacy increased with increase in the education level as well as the income level. The study reveals that there are differences between investment patterns among the high and low financially literate persons. These groups differ in term of their investment preferences, investment objectives, investment tenure, sources of investment advices and awareness level.
\end{abstract}

Keywords: Awareness level, Financial literacy, Individual investors, Investment pattern

Associate Professor, Faculty of Management, Tribhuvan University, email: jdangol@gmail.com, **Freelance Researcher, email: roieshk@gmail.com 


\section{Introduction}

Financial literacy is one of the important issues in modern finance. Financial literacy of an individual is defined as their level of understanding the financial concepts which enables them to process the financial information and make informed financial decisions about personal finance (Bhushan, 2014). It is related with how people manage their money in terms of insuring, spending, saving, investing, borrowing and retirement planning. It refers that those people who are financially literate will be able to know about the effect of interest compounding and impact of inflation on their financial decision-making.

Different methods are used in order to determine the financial literacy level of the person. Generally, it is done through the sets of questions related to economic and financial concepts and collecting the answers from the respondents. The high financially literate persons are those who are proficient in their financial knowledge as well as this proficiency is seen in their financial attitude and financial behavior (Organisation for Economic Co-operation and Development, 2005). This implies that financial knowledge, financial behavior and financial attitude are interrelated factors for financial literacy.

Financial literacy can have important implication in financial behavior related to saving, investing and borrowing. For instance, less financially literate may be unknowingly involved in financial mistakes, less likely to exercise the financial practices and less likely to be able to cope with sudden economic shocks ( Parker and Yoong, 2009). Moreover, they are less likely to participate in stock market and to choose the mutual funds with lower fees (Rooij, Lusardi, and Alessie, 2007). High financially literate can better analyze the investment avenues and invest properly, they will not be cheated by salesperson selling the financial products not suited for them (Bhushan, 2014). There is greater chance that financially literate person are more aware and are self-sufficient to decide on investment matters rather than being fooled by others.

Various other demographic factors like age, gender, income, educational qualifications can have impact on investment decisions of finance literate person. A study has shown that illiteracy is concentrated among those low income, low education, minorities and women and they are less likely to plan for their financial activities more efficiently. 
The Section II of the paper contains literature review and about research methods are included in section III. The Section IV shows empirical results, while Section V consists of the discussion and conclusion.

\section{Literature review}

Many studies had tried to define the financial literacy in different ways. As per President's Advisory Council on Financial Literacy (PACFL, 2008), Financial literacy can be defined as ability to use knowledge and skills to manage financial resources effectively for a lifetime of financial well-being.

To measure the financial literacy of the respondents, OECD approach had been initiated by the research work conducted by Bhushan (2014). Bhushan (2014) agrued that this approach was more comprehensive as it attmepted to measure the financial literacy by using its three most probabale dimensions. They were financial knowledge, financial attitude and financial behaviour.

In Netherland, Dutch DNB Household survey (DHS) investigated the causal effect of financial literacy on stock market participation. It concluded that those with low literacy level do not invest in stocks. Moreover, it also found that those with low literacy are more likely to consult with family and friends for financial advice. On the other hand, those with high literacy are more likely to read newspaper, magazines, books and rely on financial advisors (Rooij, Lusardi, \& Alessie, 2007). Similarly, low financially literate people generally prefer investment in safe financial products and hesitated to invest in risky assets (Bhushan, 2014). Similar result was found from the study made by Rooij et al. (2011) that financially literate individuals were more likely to invest in stocks.

Regarding the sources of financial decisions making, Delavande et al. (2008) had shown that financial literacy affected the financial decisions making. It further stated that low financially literate are more likely to rely on other people as their main source of financial advice and less likely to make informed investment decisions. Similarly, Thapa and Nepal (2015) had discussed that the majority of the college students possessed basic level of financial knowledge and prefered discussing with their parents about finance.

Furthermore, Al-Tamimi et al. (2009) evaluated the financial literacy of UAE individual investors participating in local financial markets and it was found that there exists the 
significant relationship between financial literacy and a set of factors believed to affect investment decisions.

In context of investment tenure, financially literate people preferred investment to be long-term, so that they are charged with minimum fees than trading done frequently and on short-term and frequently (Shinde \& Zanvar, 2014). It, further, concluded that longterm investment lead to more compounding effect and more returns.

Regarding the awareness and investment preferences, Bhushan (2014) examined the relationship between the financial literacy of salaried individuals and their awareness concerning financial products and investment preferences. It was found that there is significant relationship between them. In other words, it implied that person with higher financial literacy score were more aware about the financial products and had more knowledge about investment procedures.

Almenberg and Dreber (2012) examined the stock market participation between male and female investors while also considering the differences in financial literacy. It concluded that women were less financially literate than men and they typically participate less in stock market and mutual funds and were significantly less risk taking.

While relating the financial literacy level with demographic factors, a study financial literacy level was higher for men, older individuals and those with higher income ( Parker \& Yoong, 2009). Similarly, the study conducted by Delavande et al. (2008) concluded that women score lower than men on a measure of financial sophistication and also concluded that high education, high income and being older are associated with higher scores suggesting that there is accumulation of knowledge over time. The reverse result was found in the study conducted by Finke et al. (2012) that financial literacy scores declined among the old age. It was observed that decline in financial literacy along with the increased age was caused by the decline in cognitive ability of the person.

Most of the literature review on financial literacy has focused on demographic variables. Very few of them have covered the selected areas like financial behavior, attitude and influences and impact of these variables in investment decisions. In the Nepalese context, studies of examining the investment pattern of financially literate persons rarely found. This study tries to fill this gap by including the three important dimensions of financial literacy under OECD approach as mentioned by Bhushan (2014) for determining the 
financial literacy level of persons and evaluating their investment pattern. The three dimensions of financial literacy are categorized under independent variables. However, the demographic variables cannot be ignored so they are placed as moderating variables that moderates the relationship between the independent variables and dependent variables, i.e., investment pattern. The conceptual framework can be illustrated in the figure 1.

Figure 1 Conceptual framework of financial literacy and investment pattern

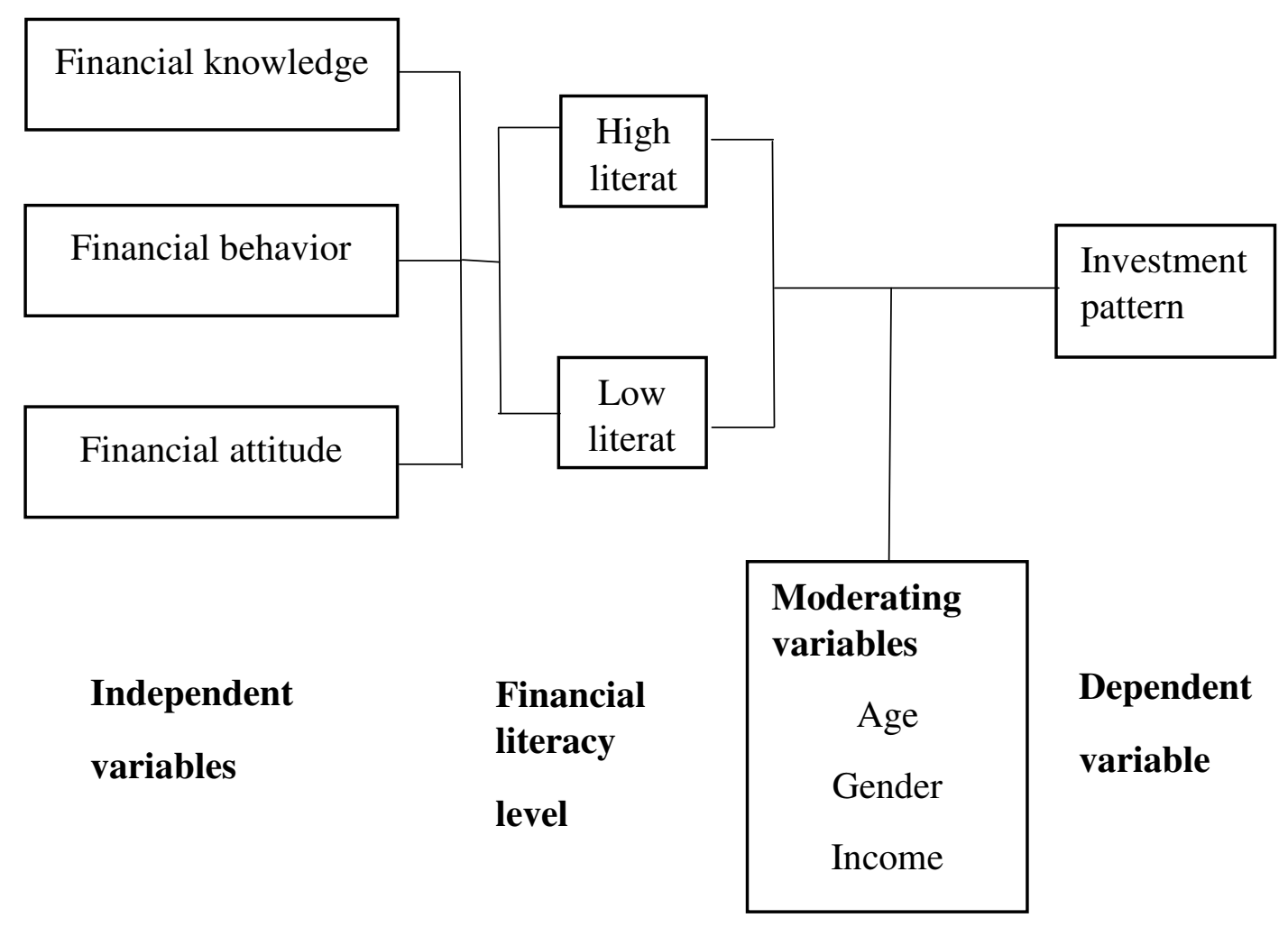




\section{Research methods}

The research design used in this study consists of descriptive and analytical research design to deal with the various issues raised. The target population for this study comprises of all investors who have invested in different investment options. The study considers individual investors are the population. The populations of investors were unknown, so sample size of 314 investors were considered using convenient sampling technique. The study was based on the collection of related data through the distribution of structured questionnaire among the individual investors. The collected data have been analyzed using SPSS software and Microsoft excel. The data were analyzed using statistical techniques like chi-square test, t-test, one way ANOVA and logistics regression.

\section{Empirical results}

\section{Respondents Profile}

Table 1 shows the respondents' profile. It shows that three-fifth of respondents surveyed were male and two-fifth were female respondents. It shows that about half of the total respondents are from the age group of 20-30 years which is followed by age group of 3140 years. Out of the total 314 surveyed respondents, $48 \%$ have educational qualification of Bachelor's degree which is followed by the Master's degree (i.e. 46\%). The least number of respondents are from the intermediate educational background. About $36 \%$ of the respondents are group under income level below Rs 20,000. The least number of the respondents are from the income level of Rs 50,001 and above.

Table 1: Respondent profile

\begin{tabular}{clcc}
\hline \multirow{2}{*}{ Demographic characteristics } & Frequency & Percent \\
\hline \multirow{2}{*}{ Gender } & Male & 186 & 59.2 \\
& Female & 128 & 40.8 \\
& $20-30$ & 171 & 54.5 \\
Age group & $31-40$ & 81 & 25.8 \\
& $41-50$ & 38 & 12.1 \\
Education & Intermediate $(+2)$ & 24 & 7.6 \\
Level & Bachelors & 19 & 6.1 \\
& & 151 & 48.1
\end{tabular}




\begin{tabular}{clcc} 
& Masters and above & 144 & 45.9 \\
Income level & Below 20000 & 112 & 35.7 \\
(Monthly in & 20001-30000 & 82 & 26.1 \\
Rs) & $30001-50000$ & 77 & 24.5 \\
& 50001 and above & 43 & 13.7 \\
\hline
\end{tabular}

\section{Financial literacy level}

For determining the financial literacy level of the respondents, three major dimensions are covered. They are financial knowledge, financial attitude and financial behavior. For each dimension, six questions were asked to the participants and scoring was done as per the median score.

Table 2 shows the descriptive values of the literacy score. It indicates that the mean financial literacy scores with average of 52.68 and with standard deviation of 8.828. This shows that respondents are high financially literate with regards to financial literacy questions with low deviation.

Table 2: Descriptive values of the literacy score

\begin{tabular}{lllllll}
\hline & & & Standard & & & \\
Literacy score & $\mathrm{N}$ & Mean & Deviation & Minimum & Maximum & Median \\
\cline { 2 - 7 } & 314 & 52.68 & 8.828 & 8 & 72 & 53.00 \\
\hline
\end{tabular}

Table 3 presents the financial literacy level of the respondents. The respondents are categorized into two groups namely "High Financially Literate" and "Low Financially Literate". This categorization of financial literacy level is done as per the median scores, i.e., the respondents whose financial literacy scores was equal or greater than the median scores were put in "High financially literate" groups. Similarly, those respondents whose financial literacy scores were less than the median scores, were put in "Low financially literate" groups. It shows that out of the total surveyed respondents, $56 \%$ of them are categorized under the high financially literate persons and $44 \%$ are categorized under low financially literate groups. 
Table 3: Financial literacy level

\begin{tabular}{lll}
\hline Financial literacy criteria & Frequency & Percent \\
\hline High Financially literate & 176 & 56.1 \\
Low Financially literate & 138 & 43.9 \\
\hline Total & 314 & 100 \\
\hline
\end{tabular}

Table 4 shows the mean scores obtained by different characteristics of sample. This survey showed that while comparing with the overall mean value (i.e. 52.86), male respondents have higher mean scores than female. Among the various age group, respondents of age group 20-30 score the highest financial mean score. Respondents of income level of Rs 50,001 and above scored highest financial literacy mean score. The least mean scores were obtained by the respondents of income level below Rs, 20,000. It shows that the highest mean scores were obtained by the respondents of educational background of Masters and above. The least scores were obtained by the respondents of the intermediate educational background.

Table 4: Financial literacy mean scores with demographic information

\begin{tabular}{cllr}
\hline \multirow{2}{*}{ Sample characteristics } & Mean & Frequency \\
\hline \multirow{2}{*}{ Gender } & Male & scores & 186 \\
& Female & 53.96 & 128 \\
\hline \multirow{2}{*}{ Age group } & YR 20-30 & 50.83 & 171 \\
& YR 31-40 & 52.56 & 81 \\
& YR 41-50 & 50.24 & 38 \\
& YR 51 and above & 52.63 & 24 \\
\hline \multirow{2}{*}{ Income Level } & below 20000 & 50.84 & 112 \\
(Monthly in Rs) & 20001-30000 & 53.12 & 82 \\
& 30001-50000 & 53.30 & 77 \\
& 50001 and above & 55.53 & 43 \\
\hline \multirow{2}{*}{ Education Level } & Intermediate(+2) & 47.00 & 19 \\
& Bachelors & 51.28 & 151 \\
& Masters and above & 54.90 & 144 \\
\hline
\end{tabular}

Financial literacy and investment pattern 
Table 5 shows the preferences of high and low financially literacy groups for various investment avenues. The result indicates that high financially literate group has the highest preferences for investment in mutual funds, shares, bonds and real estate as compared to those of low financially literate groups. Respondents of low financially literate group showed highest preferences for investment in bank deposits (savings account and fixed deposits), insurance and gold. The chi-square value of 17.482 which is statistically significant at 5\% level of significance shows that investment preferences of individual depend on the financial literacy level.

Table 5: Financially literacy groups and investment avenues

\begin{tabular}{|c|c|c|c|c|c|c|}
\hline \multirow{2}{*}{$\begin{array}{l}\text { Investment } \\
\text { avenues }\end{array}$} & \multicolumn{2}{|c|}{ High financially literate } & \multicolumn{2}{|c|}{ Low financially literate } & \multirow{2}{*}{$\begin{array}{l}\text { Chi-Square } \\
\text { value }\end{array}$} & \multirow{2}{*}{ Sig. } \\
\hline & Frequency & Percent & Frequency & Percent & & \\
\hline Mutual Fund & 24 & $13.64 \%$ & 14 & $10.14 \%$ & \multirow{8}{*}{17.482} & \multirow{8}{*}{0.008} \\
\hline Shares & 98 & $55.68 \%$ & 59 & $42.75 \%$ & & \\
\hline Bonds & 3 & $1.70 \%$ & 1 & $0.72 \%$ & & \\
\hline Real estate & 22 & $12.50 \%$ & 13 & $9.42 \%$ & & \\
\hline Bank deposits & 16 & $9.09 \%$ & 26 & $18.84 \%$ & & \\
\hline Insurance & 5 & $2.84 \%$ & 9 & $6.52 \%$ & & \\
\hline Gold & 8 & $4.55 \%$ & 16 & $11.59 \%$ & & \\
\hline Total & 176 & $100.00 \%$ & 138 & $100.00 \%$ & & \\
\hline
\end{tabular}

Table 6 presents the main purposes of investment among the high and low financially literate groups. The result shows that high financially literate groups mostly invest with the purpose of capital growth whereas low financially literate groups prefer investing for the purpose of regular income. The chi-square value of 15.948 which is statistically significant at 5\% level of significance shows that investment purposes of individual depends on the financial literacy level.

Table 6: Purposes of investment and financially literate groups

\begin{tabular}{lcccccc}
\hline \multirow{2}{*}{$\begin{array}{l}\text { Investment } \\
\text { Purposes }\end{array}$} & \multicolumn{2}{l}{ High financially literate } & Low financially literate & Chi-Square & Sig. \\
\cline { 2 - 5 } value & Frequency & Percent & Frequency & Percent & & \\
\hline Regular income & 50 & $28.41 \%$ & 59 & $42.75 \%$ & & \\
Capital growth & 79 & $44.89 \%$ & 44 & $31.88 \%$ & & \\
Tax savings & 6 & $3.41 \%$ & 4 & $2.90 \%$ & & \\
Liquidity & 27 & $15.34 \%$ & 10 & $7.25 \%$ & \\
\hline
\end{tabular}




\begin{tabular}{lcccc} 
Security & 14 & $7.95 \%$ & 21 & $15.22 \%$ \\
Total & 176 & $100.00 \%$ & 138 & $100.00 \%$ \\
\hline
\end{tabular}

Table 7 depicts the sources of advice for investment decisions among high and low financially literate groups. The result shows that high financially literate groups prefer more on own analysis for making investment decisions as compared to low financially literate groups. Low financially literate groups depend more on their family members and friends circle for making investment decisions as compared to high financially literate groups. The chi-square value is 4.599 which is statistically insignificant at $5 \%$ level of significance. It shows that sources of advice that individual seek for making investment decisions does not depends upon the financial literacy level.

Table 7: Sources of advice for investment decisions and financially literate groups

\begin{tabular}{|c|c|c|c|c|c|c|}
\hline \multirow{2}{*}{ Sources of advice } & \multicolumn{2}{|c|}{ High financially literate } & \multicolumn{2}{|c|}{ Low financially literate } & \multirow{2}{*}{$\begin{array}{l}\text { Chi-Square } \\
\text { value }\end{array}$} & \multirow{2}{*}{ Sig. } \\
\hline & Frequency & Percent & Frequency & Percent & & \\
\hline Family and friends & 57 & $32.39 \%$ & 60 & $43.48 \%$ & \multirow{4}{*}{4.599} & \multirow{4}{*}{0.10} \\
\hline Financial advisors & 28 & $15.91 \%$ & 22 & $15.94 \%$ & & \\
\hline Self-analysis & 91 & $51.70 \%$ & 56 & $40.58 \%$ & & \\
\hline Total & 176 & $100.00 \%$ & 138 & $100.00 \%$ & & \\
\hline
\end{tabular}

The investment tenure among the high and low financially literate groups has been shown in Table 8. The result shows that low financially literate groups mostly prefer investing for short term as compared to high financially literate groups. The chi-square value is 8.711 which is statistically significant at $5 \%$ level of significance. It shows that investment duration depends upon the financial literacy level.

Table 8: Investment tenure and financially literate groups

\begin{tabular}{|c|c|c|c|c|c|c|}
\hline \multirow{2}{*}{$\begin{array}{l}\text { Investment } \\
\text { Avenues }\end{array}$} & \multicolumn{2}{|c|}{ High financially literate } & \multicolumn{2}{|c|}{ Low financially literate } & \multirow{2}{*}{$\begin{array}{l}\text { Chi-Square } \\
\text { value }\end{array}$} & \multirow{2}{*}{ Sig. } \\
\hline & Frequency & Percent & Frequency & Percent & & \\
\hline$<1$ year & 40 & $22.73 \%$ & 36 & $26.09 \%$ & & \\
\hline $1-3$ years & 59 & $33.52 \%$ & 44 & $31.88 \%$ & & \\
\hline $3-5$ years & 26 & $14.77 \%$ & 34 & $24.64 \%$ & 8.711 & 0.033 \\
\hline$>5$ years & 51 & $28.98 \%$ & 24 & $17.39 \%$ & & \\
\hline Total & 176 & $100.00 \%$ & 138 & $100.00 \%$ & & \\
\hline
\end{tabular}




\section{Financial literacy and awareness level}

Table 9 depicts the risk awareness of the respondents. Greater mean value indicate the high risk and lower mean indicates the low risk of investment products. It indicates that high financially literate respondents are aware about the risk factor of investment products except for the shares and real estate investment criteria. It shows that high financially literate persons are aware about the risk associated with different investment options. There is insignificant relationship between the investment options and risk awareness level of the respondent except in the case of deposits investment products.

Table 9: Risk awareness and financially literate groups

\begin{tabular}{lccrl}
\hline & $\begin{array}{c}\text { High financially } \\
\text { literate }\end{array}$ & $\begin{array}{c}\text { Low financially } \\
\text { literate }\end{array}$ & & \\
\cline { 2 - 4 } Investment & $\begin{array}{c}\text { Mean risk awareness } \\
\text { Avenue }\end{array}$ & $\begin{array}{c}\text { Mean risk } \\
\text { awareness level }\end{array}$ & Sig. \\
\hline Mutual fund & 1.70 & 1.68 & .134 & .468 \\
Shares & 2.58 & 2.60 & -.086 & .087 \\
Bonds & 1.71 & 2.03 & -3.817 & .708 \\
Gold & 1.84 & 1.71 & 1.446 & .514 \\
Deposits & 1.18 & 1.31 & -2.271 & .000 \\
Insurance & 1.58 & 1.69 & -1.322 & .082 \\
Real estate & 2.27 & 2.39 & -.529 & .310 \\
\hline
\end{tabular}

Table 10 presents that the return awareness of the respondents. It represents that high financially literate respondents are aware about the return factor of investment products except for the mutual funds and deposits investment criteria. It shows that high financially literate persons are aware about the return associated with most of the investment options. There is insignificant relationship between the investment options and return awareness level of the respondent except in the case of shares and gold investment products. 
Table 10: Return awareness and financially literate groups

\begin{tabular}{lccrc}
\hline $\begin{array}{l}\text { Investment } \\
\text { Avenue }\end{array}$ & $\begin{array}{c}\text { High financially } \\
\text { Literate }\end{array}$ & $\begin{array}{c}\text { Low financially } \\
\text { Literate }\end{array}$ & t-value & Sig. \\
\cline { 2 - 4 } & $\begin{array}{c}\text { Mean return } \\
\text { awareness level }\end{array}$ & $\begin{array}{c}\text { Mean return } \\
\text { awareness level }\end{array}$ & & \\
\hline Mutual fund & 1.7 & 1.71 & -0.163 & 0.994 \\
Shares & 2.67 & 2.58 & 1.459 & 0.004 \\
Bonds & 1.81 & 1.87 & -0.392 & 0.836 \\
Gold & 1.96 & 1.92 & 0.524 & 0.018 \\
Deposits & 1.58 & 1.51 & 0.98 & 0.658 \\
Insurance & 1.97 & 2.03 & -0.78 & 0.181 \\
Real estate & 2.5 & 2.34 & 1.911 & 0.731 \\
\hline
\end{tabular}

Analysis for ANOVA

Table 11 shows the results of ANOVA which is used to test whether there are significant differences in financial literacy among the gender, age group and income level of the respondents. It shows that age group is found to be insignificant as its level of significant is greater than 0.05 . It denotes that there is no significant difference in financial literacy and age group of the respondents. However, gender and income level are found significant at 5\% level of significance. This implies that there are significant differences in financial literacy among the gender and various income levels of the respondents.

Table 11: Financial literacy among the gender, age group and income level

\begin{tabular}{lrl}
\hline Demographic Characteristics & F-Statistics & Sig. \\
\hline Gender & 12.012 & 0.001 \\
Age & 1.257 & 0.263 \\
Income & 6.398 & 0.012 \\
\hline
\end{tabular}

\section{Analysis of logistic regression}

Table 12 presents the results of logistic regression which is used to test whether there is significant relationship of gender, age group and income level on financial literacy level. The coefficients represent the effect of each sub-group compared to a reference group, which is subjectively selected. For example, gender category is coded as 1 if respondent is male and 0 if female. The reference group is female respondents. For age variables, 
the reference group is the respondent who is 51 and older. For income level, the reference group is the respondent who earns Rs. 50,001 or above monthly.

Table 12: Logistic regression

\begin{tabular}{lllllll}
\hline Characteristics & B & S.E. & Wald & Df & Sig. & Exp(B) \\
\hline Gender(1) & -.770 & .248 & 9.599 & 1 & .002 & .463 \\
Age & & & 7.628 & 3 & .054 & \\
Age(1) & -.880 & .484 & 3.304 & 1 & .069 & .415 \\
Age(2) & -.580 & .493 & 1.386 & 1 & .239 & .560 \\
Age(3) & .120 & .540 & .049 & 1 & .825 & 1.127 \\
Income & & & 8.039 & 3 & .045 & \\
Income(1) & 1.066 & .427 & 6.245 & 1 & .012 & 2.904 \\
Income(2) & .466 & .431 & 1.164 & 1 & .281 & 1.593 \\
Income(3) & .427 & .419 & 1.041 & 1 & .307 & 1.533 \\
Constant & .203 & .541 & .141 & 1 & .708 & 1.225 \\
\hline
\end{tabular}

According to logistic regression, there is significant relationship between the gender and financial literacy level of the respondents, since the p-value is 0.002 which is less than $5 \%$ level of significance. Similarly, the $\operatorname{Exp}(\mathrm{B})$ value for gender with financial literacy is 0.463 which indicates that the odd of being more financially literate is likely to be 0.463 times lower for male than female.

Similarly, there is insignificant relationship between the age group and financial literacy level of the respondents, since the p-value of all age group category is more than 5\% level of significance. In the same way, the Exp (B) value for age group 20-30 with financial literacy is 0.415 which states that the odd of being financially literate is likely to be 0.415 times lower for age group 20-30 than the respondents of age group 51 and older. In contrast, the $\operatorname{Exp}(\mathrm{B})$ value for age group 41-50 with financial literacy is 1.127 which states that the odd of being financially literate is likely to be 1.127 times higher for respondents of age group 41-50 than the respondents of age group 51 and older.

There is significant relationship between the income level and financial literacy level of the respondents since, the p-value is less than 5\% level of significance. Likewise, the Exp (B) value for income level of Rs below 20,000 is 2.904 which indicate that the odd of being financially literate is likely to be 2.904 times higher for respondents earning below Rs 20,000 than those earning Rs 50,000 and above. 
Table 13 presents the result of Omnibus test of model and model summary. The model is significant and well fit for developing the relationship between the dependent and moderating variables, since the significance value is less than 5\% level of significance. Similarly, Nagarkerke R-Square is the indication of explaining financial literacy level by selected moderating variables.

Table 13: Omnibus test

\begin{tabular}{lllll}
\hline & & Chi-square & df & Sig. \\
\hline Step 1 & Step & 23.980 & 7 & .001 \\
& Block & 23.980 & 7 & .001 \\
& Model & 23.980 & 7 & .001 \\
\hline -2 Log likelihood & & \multicolumn{3}{c}{ Nagelkerke R Square } \\
\hline $406.706^{\text {a }}$ & & & .099 \\
\hline
\end{tabular}

\section{Discussion and conclusion \\ Discussion}

It was found that out of the total 314 respondents, $56 \%$ of respondents were able to score higher than the median score. This implies that people are more financially literate in terms of measurement from their financial knowledge, financial attitude and financial behavior. This also implies that majority of the respondents are financially capable to make sensible investment decisions.

Regarding the mean scores obtained among different demographic characteristics of the respondents, it was found that women scored less in financial literacy questions. This result is found to be consistent with the study conducted by Delavande et.al. (2008). The reason may be that investment decisions are mostly dominated by the male. It may be happened due to the male dominated society. The mean scores on financial literacy is found to be highest under age group 20-30. This result contradicts the findings from Thapa and Nepal (2015) and Delavande et al. (2008). As they mentioned that financial literacy increases as the person gets more older due to accumulation of the knowledge and years of experiences. But in this study, younger generations scored the highest financial literacy score. Similarly, the study showed that higher income earners are more likely to be financially knowledgeable. This result is consistent to that of Delavande et al. (2008). With the increase in the income level of the person, there is increase in the need for more efficient financial decisions. 
Preferences for different investment products can be determined by people's financial literacy level. This study showed that high financially literate people choose risky invesment with the view to get the higher return as well. They are more concerned about the relationship between the risk and return factors of the investment products, i.e., higher return demands higher risk and vice versa. Similar result was established by the study conducted by Rooij et al. (2011) that financially literate people were more likely to invest in stocks. However, low financially literate person prefer the traditonal way of investment and prefer being more risk averse investors.

The finding of this study showed that high financially literate person seek capital growth as the major influencing factor for investment. Literate group do not hesitate in investing in the riskier investment options like shares and real estate. Most of the low financially literate persons are loss averse and risk averse in nature so they do not prefer riskier investment avenues. Similar to the findings by Bhushan (2014), the most preferred investment options for low financially literate person are traditonal and safe financial products like deposits, gold and insurance as the risk associated within them is at minimum. Due to this reason, these groups will not be able to take advantage of new age financial products that can provide them with higher returns.

According to Rooij et al. (2007), those people who have high level of financial knowledge tend to have capability to analyze the investment options on their own and they less prefer others opinion on their investment decisions. The same result was found in this study that high financially literate people do self analysis for their investment decisions. These people are more likely to be confident on their own financial knowledge and they are capable to evaluate the pros and cons of specific innvestment avenues. On the other hand, low financially literate persons count on their family members and friend circle for the sake of investment advices.

In terms of investment tenure, it was found that high financially literate persons are interested in long-term investment whereas low financially literate persons prefer investment for short-term. This result is consistent with the study conducted by Shinde and Zanvar (2014). However, in order to get benefits of liquidity from the short-term trading, high financially literate analyze the investment products as per their monetary requirement and trade in short-term. In case of low financially literate, they invest in 
investment products at first and neglecting for further trading. As a result, these low financially literate persons are involved in long-term investment.

In terms of awareness level, financially literate person must be more aware about the financial products. The same findings were found in this study too. The risk and return factors of the investment products should be aware to the person who is investing in it. However, high financially literate person is aware about the investment options even though he/she is not investing in it. The similar results were found by Bhushan (2014). Low financially literate persons are conscious about those financial products that they were investing only and have very little knowledge about new financial products that they were not using.

Through the binary logistic regression and one way anova test, the study found the significant relationship between financial literacy level and gender and income level. In contrast, it was found that there is insignificant relationship between literacy level and age group of the respondents. With increased income, people feel to secure their income in those investment avenues that provide them with satisfactory returns and consequently it demand higher financial knowledge.

The study found that majority of the respondent has high financial literacy level. It shows the male, respondents of age group 20-30 and income level of Rs. 50,001 and above have highest financial literacy score. In the other way, the study found that the financial literacy increased with increase in the education level as well as the income level.

\section{Conclusions}

This study analyzed the investment pattern of financially literate person taking into the cosideration of three probable dimensions of financial literacy like financial knowledge, financial behaviour and financial attitude and demographic characteristics like age, gender and income level. The literacy level of the Nepalese investors is high.

Summing up all the findings of this study, it can be concluded that there is difference in investment pattern of high and low financially literate person. The differences can be seen in their investment preferences, investment objectives, sources of advices, investment tenure and awareness level. 


\section{REFERENCES}

Almenberg, J., \& Dreber, A. (2012). Gender,stock market participation and financial literacy. Quarterly Journal of Economics, 7(3), 1-17.

Al-Tamimi, H.A.H, \& Kalli, A. (2009). Financial literacy and investment decisions of UAE investors. The Journal of Risk Finance, 10(5), 500 - 516. Retrieved August 23, 2014, from https://www.researchgate.net/publication/235289054

Bhushan, P. (2014, May). Relationship between financial literacy and investment behavior of salaried individuals. Journal of Business Management \& Social Sciences Research (JBM\&SSR), 3(5), 82-87. Retrieved from www.borjournals.com

Ciemlejaa, G., Laceb, N., \& Titkoc, J. (2014, April). Towards the practical evaluation of financial literacy: Latvian survey. 19th International Scientific Conference; Economics and Management 2014.156, 13 - 17. Latvia: Elsevier Ltd.

Danes, S. M., \& Hira, T. K. (1987). Money management knowledge of college students. Journal of Student Financial Aid, 17(1), 4-16.

Delavande, A., Rohwedder, S., \& Willis, R. (2008, September). Preparation for retirement, financial literacy and cognitive resources. Michigan Retirement Research Center, (pp. 1-50). Michigan.

Finke, M., Howe, J. S., \& Huston, S. (2012). Old age and the decline in financial literacy. Journal of Pension Economics and Finance, 22(3), 1-40.

Grifoni, A., \& Messy, F. (2013). Current status of national strategies for financial education: A comparative analysis and relevant practices. OECD Publishing (132). Paris: OECD Working Papers on Finance, Insurance and Private Pensions. Retrieved from http://www.oecd.org/publications/Policybriefs

Grohmann, A., Kouwenberg, R., \& Menkhoff, L. (2014). Financial literacy and its consequences in the emerging middle class. Kiel Working Paper (pp. 1-39). Kiel Institute for the World Economy. Retrieved from http://www.ifw-kiel.de

Heenkenda, S. (2014). Inequalities in the financial inclusion in Sri Lanka: An Assessment of the Functional Financial Literacy. MPRA Paper No. 54419., (pp. 38-54). 
Ibrahim, D., Harun, R., \& Isa, Z. M. (2009, December). A Study on financial literacy of malaysian degree students. Cross-cultural Communication, 5(4), 51-59.

Kline, P. (1999). The handbook of psychological testing. London: Routledge publication.

Kulkarni, M., \& Rawal, D. (2016, May). Investment patterns of college teachers with respect to Navi-Mumbai city. International Research Journal of Multidisciplinary Studies, 2(5), 1-13.

Levine, D. M., Krehbiel, T., Berenson, M., \& Viswanathan, P. (2010). Business Statistics. Delhi: Pearson.

Lusardi , A., \& Mitchell, O. (2007a). Baby boomer retirement security: The roles of planning, financial literacy, and housing wealth. Journal of Monetary Economics, $54,205-224$.

Lusardi, A., \& Mitchell, O. S. (2006). Financial literacy and planning. Pension Research Council Working Paper, (pp. 1-27). Retrieved from http://www.prc.wp.com

Lusardi, A., \& Mitchell, O. S. (2014). The economic importance of financial literacy: Theory and evidence. GFLEC Working Paper Series, (pp. 5-44). Retrieved from http://www.jstor.org/stable/24433857

Nepal Rastra bank. (2012). NRB Strategic Plan 2012-2016.

Nithya, D., \& Rajeswari , K. (2014, July). Impact of demographic factors on mutual fund investments in South India. Australian Journal of Basic and Applied Sciences, $8(10), 158-165$.

Nunnally, J. (1978). Psychometric Theory. New York: McGraw-Hill.

Organisation for Economic Co-operation and Development. (2005). Improving financial literacy: Analysis of issues and policies. New York:OECD.

Parker, A., Yoong, J., Bruine de , B., \& Will, W. (2008). (Over)confidence and economic behavior. Conference on Understanding Economic Decision-Making,2,45-60

Parker, A. M., \& Yoong, J. (2009, March 13). Defining and measuring financial literacy. SSRN Electronic Journal, 2, 1-29. doi:0.2139/ssrn.1498674

President's Advisory Council on Financial Literacy (PACFL). (2008). Annual Report to the President. 
Remund, D. (2010). Financial literacy explicated: The case for a clear definition in an increasingly complex economy. The Journal of Consumer Affairs, 44(2), 276295.

Rooij, M., Lusardi, A., \& Alessie, R. (2007, January). Financial literacy and stock market participation. Journal of Finance and Economics, 101(2), 449-472.

Rooij, V., C.J., M., Lusardi, A., \& Alessie, R. (2011). Financial literacy and stock market participation. Journal of Financial Economics, 101, 449-472.

Sekaran, U., \& Bougie, R. (2016). Research methods for business: A skill-building approach. New Delhi: Wiley \& Sons.

Shinde, D. C., \& Zanvar, M. P. ( 2014, September). An empirical study on factors influencing in investment decision making in Pune. International Research Journal of Management and Commerce, 1(6), 10-23.

Shrestha, H. B. (2008). Learning statisitcs and SPSS in Tandem. Kathmandu: Ekta Publisher.

Sood, D., \& Kaur, D. (2015, February). A study of saving and investment pattern of salaried class people with special reference to Chandigarh. International Journal of Research in Engineering, IT \& Social Sciences, 5(2), 1-15.

Stango, V., \& Zinman, J. (2014). Limited and varying consumer attention: Evidence from shocks to the salience of bank overdraft fees. The Review of Financial Studies, 27(4), 990-1030.

Sucuahi, W. T. (2013). Determinants of financial literacy of micro entrepreneurs of Davao city. International Journal of Accounting Research, 1(1),1-9.

Thapa, B. S., \& Nepal, S. R. (2015, February). Financial literacy in Nepal: A survey analysis from college students. NRB Economic Review,2(3), 50-74. 